\title{
Status of Financial Literacy Centers in Karnataka
}

Sangeetha R, ${ }^{*}$ Jain Mathew† and Sheethal C Franclineł

\begin{abstract}
Financial literacy as a key pillar for a better financial system, helps to improve the financial situation of the citizens by achieving higher economic growth. This study aims to find out the status of Financial Literacy Center, among 30 districts in Karnataka over a period of 9 years (2008-2009 to 2016-17). The variables considered for the study are Deposits, Advances, Credit Deposit Ratio (CD ratio), Financial Literacy Centers (FLC) and Number of Reporting Offices (no. of reporting offices) available in the district. Data has been collected from various secondary sources like RBI, SLBC, Data Base on Indian Economy, etc., and analyzed using Descriptive statistics, Regression and ANOVA. It is found that there is an impact of FLC on $\mathrm{CD}$ ratio. However growth of the $\mathrm{CD}$ ratio is not in alignment with the growth in FLC.
\end{abstract}

Keywords: Credit Deposit Ratio, Financial Literacy Center, Reporting Office, Credit, Deposit, Financial Literacy

\section{Introduction}

The major issue in India revolves around factors like poverty, illiteracy, pollution, sustainability and under development

*Christ University; sangeetha.r@christuniversity.in

† Christ University; jainmathew@christuniversity.in

$\ddagger$ Christ University; sheethal.francline@christuniversity.in 
\&education system. The role played by financial intermediaries and banking sector in mobilising deposits and paying credits to various sectors of an economy leads to sustainable growth. It is not possible to attain sustainable growth without persistent financial institutions. Access to transaction account is the door step towards financial inclusion, which is possible only through banking and financial institutions. "Financial Inclusion is the process of ensuring access to appropriate financial products and services needed by vulnerable groups especially excluded persons of the population with the provision of equal opportunities." Reserve Bank of India, (2011). Financial inclusion is only possible through financial literacy. Financial literacy refers to the set of skills and knowledge that allows an individual to make informed and effective decisions which enhances financial wellbeing. Access to financial literacy leads to better standard of living. It is the door step towards prosperity. This will also help to earn, manage, and multiply money. The lack of financial literacy can usher to making poor financial decisions and may have worse effects on the financial health of an individual. As a measure towards financial inclusion, in August 2014 "Pradhan Mantri Jan-Dhan Yojana" (PMJDY) was launched by the Government of India. As reported by RBI, 4,90,298 unbanked villages with population less than 2000 were disclosed and rationed to various banks for coverage under second phase of Pradhan Mantri Jan Dhan Yojna Reserve Bank of India, (2016). The main objective of this initiative is to increase the availability of financial services such as bank accounts, insurance, pension, credit facilities, etc. to the weaker section. Through this programme in India, 224.8 million new accounts have been opened and around USD 403 billion has been deposited with the banks by July 2016. "Rupay" debit cards worth Rs.182.9 million have been provided to the users till July 2016 (India Brand Equity Foundation, 2016). In 2017, the state wise household coverage on account opening reported in Karnataka is $99.97 \%$. Under state wise account opening report as on 31 may, 2017, it is stated that Karnataka has a total of $1,00,73,806$ beneficiaries from both rural or semi urban centre bank branches and among them 74,44,462 Rupay cards are issued. Ministry of Finance, (2017). 
Financial Literacy Centres (FLC) are provided by government, which are designed to provide financial awareness and promote \& develop the financial literacy skill among students and adults. The FLCs will bequeath financial literacy campaigning like why save, why save early, which source is the best, why borrow only from Banks, why repay in time, why to insure yourself, why plan for your retirement, etc. FLCs and rural branches of banks may adopt a tailored approach for different target groups viz. farmers, micro and small entrepreneurs, school children, SHGs and senior citizens, etc. Reserve Bank of India, (2016). Specifically the purpose of the study is to find out whether there is any change in credit deposit ratio while there is an increase in number of financial literacy centres and number of reporting offices.

This paper is organised as such: section 2 reviews the relevant literature on current deposit ratio, financial inclusion and bank performance finally helps to find out the financial literacy level in the districts which is taken in the study, section 3 explains the objectives of the study followed by, section 4 data and methodology applied for the study, section 5 depicts result and inferences and session 6 concludes the study.

\section{Literature Review}

With a view to bring forward an adequate foundation for the present investigation, a brief review of literature has been made in this section:

The study conducted by Biswal \& Gopalakrishna, (2014) made an attempt to discover the impact of CD Ratio on bank profitability. The result shows that determinants of bank profitability have varied impact for banks under high $C D$ ratio and low $C D$ ratio categories. In a study conducted by Rao, (2015) revealed that most of the banks have an overall increase in loans and advances, over dues and ratio of over dues to loans and advances. However most of the banks recorded very less overall CD ratios. A study conducted by Centre for Toxicology and Developmental Research (CEFT), (2016) analyzed Credit Deposit Ratio (CDR) of twenty one states in India in order to empirically examine its importance on 
growth in Gross State Domestic Product (GSDP) and State Own Tax Revenue (SOTR). It was found that CDR and GSDP growth of the states are interdependent. CDR and SOTR have unidirectional causal relationship. The higher economic growth induced by raising CD Ratio will trigger more trade, commerce, and business opportunities which in turn help the states to mobilize more tax revenue. Kumar \& Verma, (2008) in their study revealed that the foreign bank groups have exhibited the best credit deposit ratio comparing to public sector banks. Kumar D. , (2013) made an attempt and found that the various factors that justify the performance of commercial banking in Bihar through CD ratio. Research suggest that banks still need to take much more proactive measures in increasing the credit flow by opening more branches in the unbanked areas, and relaxing some of their stringent credit norms. Sharifi \& Akther, (2016) conducted and revealed that there is no significant impact of independent variables credit deposit ratio (CDR) on dependent variables return on asset (ROA) and return on equity (ROE). However there is significant impact of independent variables (CDR) on dependent variables net interest margin (NIM). The positive impact of CreditDeposit on bank's financial performance shows that the banks charge more than what they pay on interest expense from the depositors. Also increase in loan has positive effect on banks profitability. Kanchu, (2012) found and concluded that the growth of number of District Central Cooperative Banks and their branches have negative trend up to certain period and later there is a negligible positive trend. However the membership in cooperative banks has been increasing. A study undertaken by Ibrahim M. S., (2011) concluded that the Scheduled Commercial Banks in India have significantly improved their operational performance. Nair, (2016) revealed in his report on financial inclusion in Kerala, that innovative solutions are required to overcome physical bottlenecks and social and economic backwardness. Further analysis of the mapped data shows that much of banking function in the state has been limited to savings only. A study conducted on "Financial Inclusion and its determinants" by Kumar N., (2013) discovered that deposit penetration and credit penetration have a positive correlation. Biswas \& Gupta, (n.d.) identified that Occupation, 26 
Educational Background and Household Income are statistically significant demographic factors influencing financial literacy. The mean financial literacy of rural respondents is found to be much lower than that of urban respondents. M \& R, (2013) has identified a significant progress has already been achieved in the State of Karnataka through financial inclusion. R, (2012) observed that inclusive bank financial activities greatly influence poverty reduction but marginally determine national economic growth and Financial Intermediation through enhanced Bank Branch Networks, Loan to Rural Areas, and Loan to Small Scale Enterprise given about $50 \%$ relatedness between variables on either side of the equation. A study has been made by Zwedu, (2014) revealed that despite huge initiative in the last ten years, financial inclusion is still very low. Lack of physical access is one of the major problems in enhancing financial inclusion. Nayak, (2012) in his study discovered that Indian growth is not an inclusive growth because the real GDP percent change per annum and growth of real GDP per head per annum are increasing whereas consumption inequality in India is increasing rapidly after 2004-2005. Though poverty or the number of poor has been decreasing over the years the trend is not spectacular. Evidences from Han \& Melecky, (2013) revealed that on an average, greater access to bank deposits enhance resilience of the deposit funding base of the banking sector during financial stress.

Based on the previous studies it is clear that most of the study is related to $C D$ ratio. The factors affecting the growth of $C D$ ratio is also entirely different like net interest margin, cost of funds, capital reserve, GDP etc. In none of the studies they took no of FLC and no. of reporting offices will affect the growth of $C D$ ratio. By analysing this we can determine the financial literacy level of people in Karnataka.

\section{Objectives of the Study}

This study has been undertaken with following objectives in mind: 
1. To know the trends in Financial Literacy Centers in Karnataka.

2. To determine the trends in $C D$ ratio of 30 districts in Karnataka.

3. To analyze the impact of FLC and reporting office on CD ratio.

\section{Data and Methodology}

This paper is an attempt to study the impact of Financial Literacy Center's, number of reporting offices on $\mathrm{CD}$ ratio among 30 districts in Karnataka. The study is based on secondary data. The required data is collected from various sources like RBI, SLBC and Data Base on Indian Economy etc. The variables used in this study are number of reporting offices, deposits and advances of these districts and number of Financial Literacy Centres in Karnataka. Data for 9 years starting from 2008-2009 to 2016-2017 has been used for the analysis since the Financial Literacy Centres were established in Karnataka during 2008. Hence the data on district wise number of reporting offices and aggregate deposit and bank credit available in scheduled commercial banks are collected accordingly. The frequency of the data is fixed at fourth quarter of the financial year. Descriptive statistics is used to analyse the structure of the data. To figure out the trends in variables, graphs were used. To understand the casual effect relationship between dependent and independent variable regression analysis is used. The results for the test were obtained using SPSS statistical software package.

\section{Results and Inference}

We now present major results and inferences.

\subsection{Descriptive Statistics}

Descriptive statistics deals with presentation of numerical facts, or data, in either tables or graphs form used for analyzing the data. An analysis of characteristics helps to understand whether the data 
is reliable and credible to the study. It can be done using descriptive statistics.

Table 1 Descriptive statistics

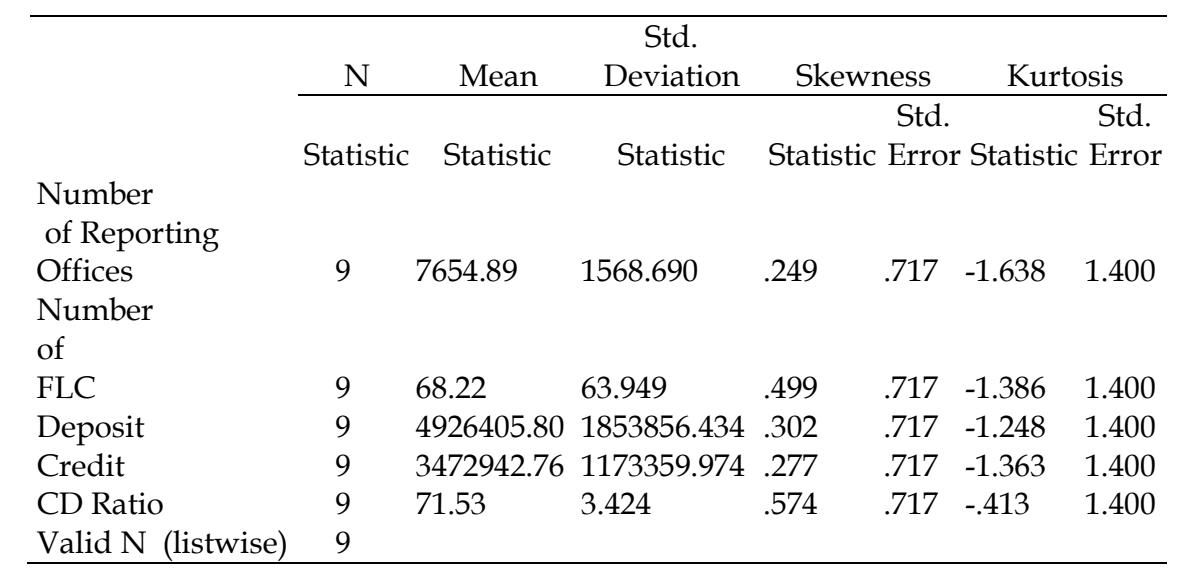

The result of descriptive statistics in Table 1 provides a clear picture on reporting offices and Financial Literacy Center functions in Karnataka as well as the CD ratio reflecting from credits and deposits of each district among Karnataka. The skewness of the data for all the variables is less than absolute value. The data which is near to zero is considered as symmetrical. Here all the values except $C D$ ratio are less than 0.5 which is negligible and data is proved to be normally distributed. Kurtosis is a statistical measure used in combined weight of distribution tail. Normal distribution relies on kurtosis statistic which is equal to zero.

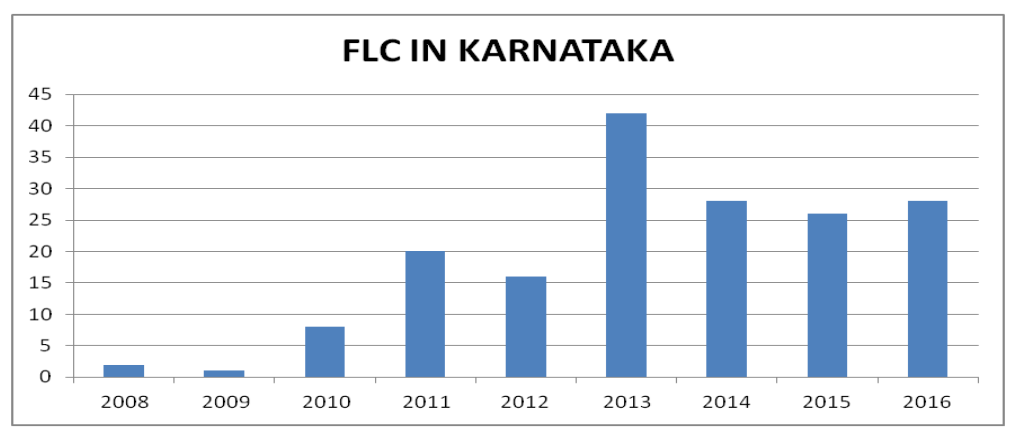

Fig 1 Trends in Financial Literacy Center in Karnataka 
2016. In Karnataka FLC was established in the districts like Koppal and Raichur during 2008. Based on the data it can be inferred that there is continuous improvement in the number of Financial Literacy Centres between 2008 and 2013. However, there exist a sudden decline in FLC immediately after 2013. During 2013 the number of FLC ranges between $40 \& 50$. In 2013, the highest no of FLC is 42, out of which 6 from Uttar Kannad and in 2009 the highest number of FLC was 1, which belongs to Tumkur. As per the 2016statistics across Karnataka there are171 FLC's.

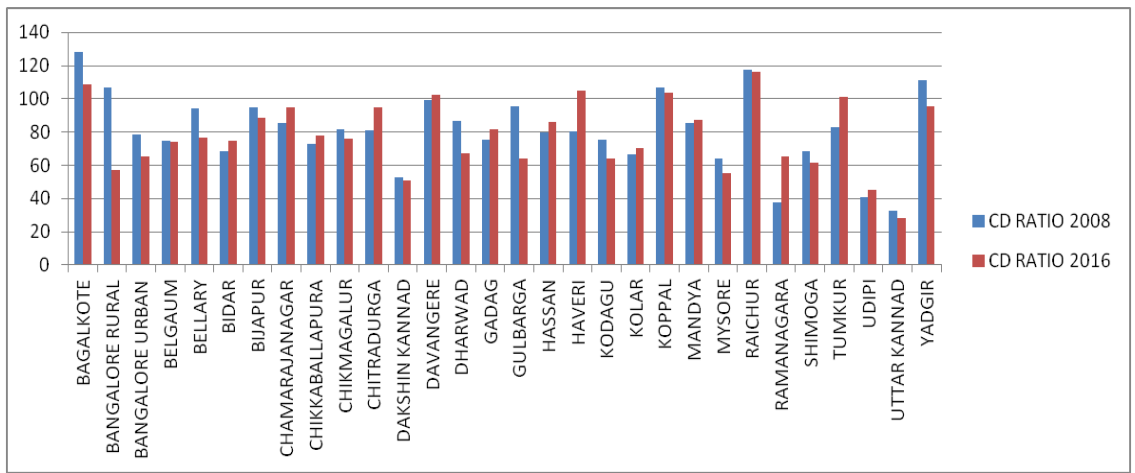

Fig 2 Trends in Financial Literacy Center in Karnataka

In Figure. 2 it can be observed that the comparison of $C D$ ratio between 30 districts in Karnataka during 2008 and 2016.Here CD ratio is considered for two extreme years, 2008 and 2016 except Yadgir district. Yadgir was one of the 30 districts in Karnataka, carved out from the former Gulbarga district in April 2010. So for this district alone $\mathrm{CD}$ ratio is considered as 2010 data. It is observed that out of 30 districts, 13 districts have shown an increase in the $\mathrm{CD}$ ratio and the remaining 17 have shown a decrease. While considering both the years (2008 and 2016), Bangalore rural has the highest variation in the $\mathrm{CD}$ ratio, whereas Raichur has the lowest variation in the $C D$ ratio. Whereas Bagalkote has the highest $C D$ ratio and the lowest was maintained by Uttar kannad. 


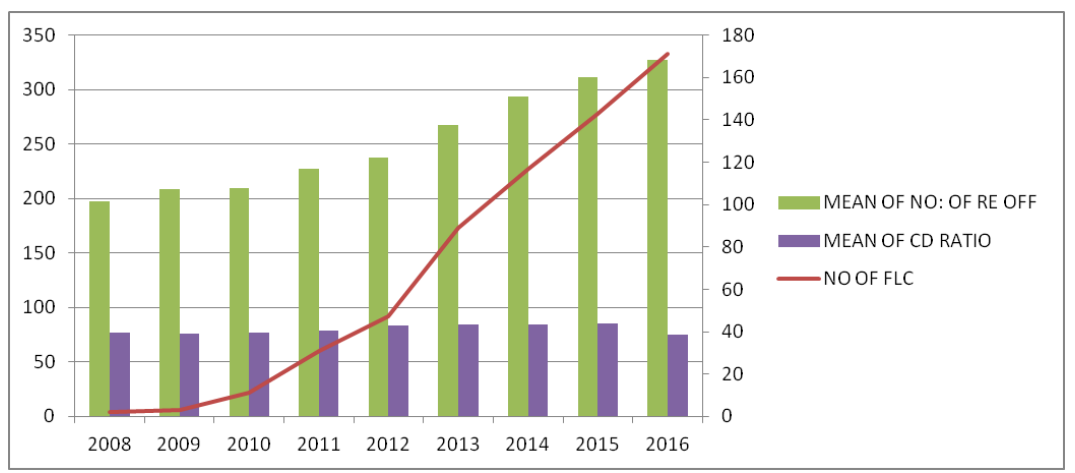

Fig 3 Status of CD Ratio, number of Reporting Offices and Financial Literacy Center

An interesting fact to point out is about the increment in the number of FLC and the average of reporting offices from 2008 to 2016. Figure 3 shows the calculated drops of increment in the mean of number of reporting offices and the number of FLC. In 2008, there was only one or two Financial Literacy Center was available, later in 2016 its altogether 171 Financial Literacy Center are available in various districts around Karnataka. It is clear that, there is not much huge variation in the mean of $\mathrm{CD}$ ratio over these years.

\subsection{Regression Analysis}

Regression analysis is a statistical process which helps the researcher to identify whether there is any significant relationship between dependent and independent variables. Using regression analysis the relationship between the $\mathrm{CD}$ ratios, the dependent variable, and the number of reporting offices, number of FLC, deposits and advances independent variables were found.

Table 2 Model summary of CD ratio and the independent variables

\begin{tabular}{llllll}
\hline Model & $\mathrm{R}$ & R Square & $\begin{array}{l}\text { Adjusted } \\
\text { Square }\end{array}$ & $\begin{array}{l}\mathrm{R} \\
\text { Std. Error of the } \\
\text { Estimate }\end{array}$ \\
\hline 1 & $.985^{\mathrm{a}}$ & 969 & .939 & .848 \\
\hline
\end{tabular}

Table 2 depicts that there exist $\mathrm{R}=0.985$ Strong correlation between $\mathrm{CD}$ ratio and advances, deposits, number of FLC, number of reporting offices. 
$\mathrm{R} 2=0.969$ express that the independent variables explains $96.9 \%$ of the variability of the dependent variable, CD ratio in this model. Adjusted R2 $=0.939$ reflects that the independent variable explains $93.9 \%$ of the variability of the dependent variable, $C D$ ratio in the population.

Table 3 Regression analysis of CD ratio and the constant variables

Anova $^{\mathrm{a}}$

\begin{tabular}{lccccc}
\hline \multicolumn{1}{c}{ Model } & Sum of Squares & df & Mean Square & F & Sig \\
\hline Regression & 90.940 & 4 & 22.735 & 31.636 & $.003^{\mathrm{b}}$ \\
Residual & 28.75 & 4 & .719 & & \\
Total & 93.814 & 8 & & & \\
\hline
\end{tabular}

The F-ratio in the ANOVA table is the ratio of the mean sum of squares for regression to the mean sum of squares for the residuals. It tests whether the regression model is a good fit for the data. The table 3 shows that the independent variables statistically significant to predict the dependent variable, $F(4,4)=31.636, p<.0005$ (i.e., the regression model is a good fit for the data.

\section{Conclusion}

From the study it is clear that, there is an impact of FLC on CD ratio. Though FLC act as catalyst to improve CD ratio among these 30 districts in Karnataka, growth of the CD ratio is not in alignment with the growth in Financial Literacy Center. Analytical tools like descriptive statistics, Anova, regression were used to know the statistical significance in this study. While comparing the values of continuous 9 years, it is clear that there isa fluctuation in the CD ratio, exhibiting an improvement in the banking penetration in Karnataka. As per this study, deposit mobilization among FLC is at low level, sothe $C D$ ratio of the state also is low. Low $C D$ ratio may be due to the availability of credit to the poor from unorganized sector. Hence,there may be low demand for bank credit for productive purposes.

Low $\mathrm{CD}$ ratio in the state is not only is the consequence of poor mechanism like lender, borrower, facilitating agencies and regulatory body but also the unwillingness on the part of the banks to sanction loans for the low creditworthiness of the 
entrepreneurs in the state. As discussed in the literature review, there may be a lot of other factors like Net Interest Margin, Cost of Funds, Return on Asset, and Return on Equity etc., which may affect the level of $\mathrm{CD}$ ratio.

\section{Scope for further research}

The findings imply that $\mathrm{CD}$ ratio has improved overtime, but its growth is not as per the growth of reporting offices and Financial Literacy Center. In this paper, the casual effect between dependent variable $C D$ ratio and independent variables like reporting offices, Financial literacy centers, deposits and advances are analysed. However there are many other factors which may affect the growth of $\mathrm{CD}$ ratio like Net Interest Margin, Cost of Funds, Return on Asset, and Return on Equity etc. Hence future research work can concentrate on identifying the effect of Net Interest Margin, Cost of Funds, Return on Asset, and Return on Equity on CD ratio.

\section{Acknowledgement}

We thank CHRIST (Deemed to be University) for giving us the opportunity to conduct Major Research Project (MRPDCM1522) on the topic Financial Literacy and Investment Behavior of Middle Class Families in Karnataka.

\section{References}

Atkinson, A., \& Messy, F.-A. (2012). Measuring Financial Literacy: Results of the OECD /International Network on Financial Education (INFE) Pilot Study. Paris: OECD Working Papers on Finance, Insurance and Private Pensions.

Biswal, B. P., \& Gopalakrishna, R. (2014). CD Ratio and Bank Profitability: An Empirical Study. International Journal of Financial Management, 1-10.

Biswas, S., \& Gupta, A. (n.d.). Financial Inclusion and Financial Literacy:

A Comparative Study in their Interrelation between Selected Urban and Rural Areas in the State of West Bengal. IOSR Journal of Economics and Finance (IOSR-JEF), 67-72. 
Centre for Toxicology and Developmental Research (CEFT). (2016). Estimation of Base Lineand Optimal Credit Deposit Ratio in Odisha. Xavier University,Bhubhaneshwar India.

Goel, S., \& Kumar, R. (2016). Analysis of Cash - Deposit Ratio \& Credit Deposit Ratio of Public Sector Banks in India. International Journal of Research in Management, Science ETechnology (E-ISSN: 2321-3264) , 4 (2), 72-74.

Han, R., \& Melecky, M. (2013). Financial Inclusion for Financial Stability Access to Bank Deposits and the Growth of Deposits in the Global Financial Crisis. Policy Research Working Paper 6577, 1-24.

Ibrahim, M. S. (2011). Operational Performance of Indian Scheduled Commercial - An Analysis. International Journal of Business and Management , 6 (5), 120-128.

India Brand Equity Foundation. (2016). Banking. Retrieved 2017, from Indian Brand Equity Foundation: https://www.ibef.org/ download/ Banking-September-2016.pdf

Kanchu, T. (2012). Performance Evaluation of DCCB's in India- A Study. Asia Pacific Journal of Marketing \& Management Review , 1 (2), 169-180.

Kumar, D. (2013). Performance of banking through credit-deposit ratio in Bihar: A study of last decade. International Journal of Application or Innovation in Engineering \& Management(IJAIEM), 2 (10), 210-218.

Kumar, N. (2013). Financial Inclusion and its Determinants: Evidence from State Level Empirical Analysis in India. 1-23.

Kumar, N., \& Verma, P. (2008). Credit Deposit Ratio and Ownership Structure in Indian Banking Structure: An Empirical Analysis. Global Academic Society Journal: Social ScienceInsight III , 1 (4), 4-17.

Kumar, S., \& Anees, M. (2013). Financial Literacy \& Education: Present Scenario in India. International Journal of Engineering and Management Research , 83-87.

M, R. H., \& R, S. (2013). Financial Inclusion in Karnataka: A Study on Bankeres Initiatives. IRACST - International Journal of Commerce, Business and Management (IJCBM), 2 (6),344-352.

Ministry of Finance. (2017). www.pmjdy.gov.in. Retrieved 2017, from https://www.pmjdy.gov.in/statewise-statistics:

https://www.pmjdy.gov.in/statewise-statistics

Nair, T. (2016). Report on State of Fianancial inclusion in Kerala. Kerala: MIX.

Nayak, R. K. (2012). Financial Inclusion through Cooperative Banks: A Feasible Option for Inclusive Growth. Indore Management Journal (IMJ), 4 (3), 9-17. 
Onaolapo, A. R. (2015). Effects of Financial Inclusion of Economic Growth of Nigeria (1982-2012). International Journal of Business and Management Review , 3 (8), 11-28.

Rao, K. S. (2015). A Comparative Analysis of Loans and Advances in Selected Urban Co-operative Banks. National Monthly Refered Journal of Research in Commerce \& Management

, 2 (10), 11-22.

Reserve Bank of India. (2016). Credit Delivery and Financial Inclusion. Retrieved 2017, from Reserve Bank of India: https://www.rbi.org.in/ Scripts / AnnualReportPublications.aspx?Id=1177

Reserve Bank of India. (2011). Financial Inclusion and Financial Literacy. Retrieved 2017, from OECD: https://www.oecd.org/ finance/ financial-education/48303408.pdf

Reserve Bank of India. (2016). Financial Literacy Material. Retrieved 2017, from Reserve Bank of India: https://rbi.org.in/ Scripts/ NotificationUser.aspx?Id=7844\&Mode $=0$

Sharifi, O., \& Akther, J. (2016). Performance of Banking through Credit Deposit Ratio in Public Sector Bank in India. IRACST-International Journal of Research in Management ETechnology (IJRMT) , 6 (4), 14-18.

Zwedu, G. A. (2014). Financial inclusion, regulation and inclusive growth in Ethiopia.

Ethiopia: DFID-ESRC Growth Research Programme (DEGRP). 